PACS: $87.14 . \mathrm{C}++\mathrm{c}$, 87.16.Dg

\title{
MOLECULAR DYNAMICS STUDY OF AMYLOIDOGENIC MUTANTS OF HUMAN LYSOZYME
}

\author{
U. Tarabara*, (D) Trusova, (D) Kus, IDO. Ryzhova, (D) Gorbenko \\ Department of Nuclear and Medical Physics, V.N. Karazin Kharkiv National University \\ 4 Svobody Sq., Kharkiv, 61022, Ukraine \\ *E-mail: uliana.tarabara@gmail.com \\ Received 11 November 2018, accepted 5 December 2018
}

\begin{abstract}
The mutants of human lysozyme are capable of fibril formation implicated in the etiology of familial systemic or renal amyloidosis. A series of $100 \mathrm{~ns}$ thermal unfolding molecular dynamics (MD) simulations with WT human lysozyme and its seven amyloidogenic variants (I56T, D67H, F57I, W64R, Y54N, F57I/T70N and T70N/W112R) have been performed at $500 \mathrm{~K}$. The molecular dynamics simulations were performed with GROMACS software (version 5.1) using the CHARMM36m force field. The MD results have been analysed in terms of the parameters characterizing both the global and local protein structure, such as the backbone root mean-square deviation, gyration radius, solvent accessible surface area, the root mean-square fluctuations and the secondary structure content. Depending on the observed effects, the examined variants of human lysozyme have been roughly divided into three groups comprising of mutants with faster (Y54N and F57I/T70N), similar (D67H and I56T) or slower (W64, F57I and T70N/W112R) unfolding rate compared to the wild-type counterpart. The analysis of the protein fluctuational behavior revealed that in most mutants the $\beta$-domain displays stronger fluctuations (except the W64R and F57I) and higher flexibility of the C-and D-helices relative to the native lysozyme with the exception of W64R and Y54N which show marked decrease (W64R) or increase (Y54N) in mobility of almost all residues. The analysis of secondary structure evolution provided evidence for higher stability of $\alpha$-domain compared to $\beta$ domain. The results obtained reinforce the idea that mutation-induced global structural destabilization is not the only factor contributing to protein misfolding, the modifications in conformation and dynamics of selected protein regions may also play significant role in amyloid fibril formation.
\end{abstract}

KEYWORDS: Human lysozyme, amyloidogenic mutants, molecular dynamics, protein aggregation, amyloid

\section{МОЛЕКУЛЯРНО-ДИНАМИЧЕСКОЕ ИССЛЕДОВАНИЕ АМИЛОИДОГЕННЫХ МУТАНТОВ ЛИЗОЦИМА ЧЕЛОВЕКА}

У. Тарабара, В. Трусова, К. Вус, О. Рижова, Г. Горбенко

Кафедра ядерной и медицинской физики, Харьковский национальный университет имени В.Н. Каразина пл. Свободьи 4, Харьков, 61022, Украина

Мутанты лизоцима человека способны к образованию фибрилл, вовлеченных в этиологию семейного системного или почечного амилоидоза. В работе была проведена серия 100 нс молекулярно-динамических (МД) симуляций дикого типа лизоцима человека (WT) и его семи амилоидогенных мутантов (I56T, D67H, F57I, W64R, Y54N, F57I / T70N и T70N / $\mathrm{W} 112 \mathrm{R})$ при температуре $500 \mathrm{~K}$. Молекулярно-динамическое моделирование проводилось с использованием программного пакета GROMACS (версия 5.1) в силовом поле CHARMM36m. Результаты MD моделирования были проанализированы в терминах параметров, характеризующих как глобальную, так и локальную структуру белка, таких как среднеквадратичное отклонение остова цепи, радиус инерции, площадь поверхности, доступной для растворителя, среднеквадратичные флуктуации остова цепи и содержание вторичной структуры. В зависимости от наблюдаемых эффектов исследуемые мутанты лизоцима человека были условно разделены на три группы: мутанты с более быстрой (Y54N и F57I / T70N), подобной (D67H и I56T) и более медленной (W64, F57I и T70N / W112R) скоростью разворачивания по отношению к WT белку. Анализ флуктуационного поведения белка показал, что у большинства мутантов $\beta$-домену присущи более сильные флуктуации (за исключением W64R и F57I) и большая гибкость C- и D-спиралей по сравнению с нативным лизоцимом, за исключением W64R и Y54N, у которых выявлено заметное снижение (W64R) или увеличение (Y54N) подвижности почти всех остатков. Анализ эволюции вторичной структуры свидетельствует о более высокой стабильности $\alpha$-домена по сравнению с $\beta$-доменом. Полученные результаты подтверждают идею о том, что глобальная структурная дестабилизация, вызванная мутацией, не является единственным фактором, способствующим неправильному сворачиванию белков, а изменения в конформации и динамике отдельных областей полипептидной цепи могут также играть важную роль в образовании амилоидных фибрилл.

КЛЮЧЕВЫЕ СЛОВА: Лизоцим человека, амилоидогенные мутанты, молекулярная динамика, агрегация белков, амилоид

\section{МОЛЕКУЛЯРНО-ДИНАМІЧНЕ ДОСЛІДЖЕННЯ АМІЛОЇДОГЕННИХ МУТАНТІВ ЛІЗОЦИМУ ЛЮДИНИ У. Тарабара, В. Трусова, К. Вус, О. Рижова, Г. Горбенко}

Кафедра ядерної та медичної фізики, Харківський начіональний університет імені В.Н. Каразіна пл. Свободи 4, Харків, 61022, Україна

Мутанти людського лізоциму здатні утворювати фібрили, які пов'язані з етіологією системного або ниркового амілоїдозу. Було проведено серію 100 нс молекулярно-динамічних (МД) симуляцій дикого типу (WT) людського лізоциму та його семи амілоїдогенних мутантів (I56T, D67H, F57I, W64R, Y54N, F57I / T70N i T70N / W112R) при температурі 500 K. Молекулярно-динамічне моделювання було проведене за допомогою програмного пакету GROMACS (версія 5.1) в силовому полі CHARMM36m. Результати МД моделювання були проаналізовані в термінах параметрів, що характеризують як глобальну так і локальну структуру білка, таких як середньоквадратичне відхилення остову ланцюга, радіус інерції, площа поверхні, доступна для розчинника, середньоквадратичні флуктуації та вміст вторинної структури. В залежності від (C) Tarabara U., Trusova V., Vus K., Ryzhova O., Gorbenko G., 2018 
спостережуваних ефектів, досліджувані мутанти були умовно розділені на три групи: мутанти з більшою (Y54N та F57I/T70N), подібною (D67H та I56T) та меншою (W64, F57I та T70N/W112R) швидкістю розгортання у порівнянні з WT білком. Аналіз флуктуаційної поведінки білка показав, що у більшості мутантів $\beta$-домену притаманні сильні флуктуації (за винятком W64R i F57I) та більша гнучкість C- i D-спіралей у порівнянні з нативним лізоцимом, за винятком W64R та Y54N, у яких виявлено помітне зниження (W64R) або зростання (Y54N) рухливості практично всіх залишків. Аналіз еволюції вторинної структури свідчить про більш високу стабільність $\alpha$-домену порівняно $3 \beta$-доменом. Отримані результати підтверджують думку про те, що глобальна структурна дестабілізація, викликана мутацією, не є єдиним фактором, який сприяє неправильному згортанню білків, а модифікація конформації та динаміки окремих областей поліпептидного ланцюга також можуть відігравати важливу роль у формуванні амілоїдних фібрил.

КЛЮЧОВІ СЛОВА: Лізоцим людини, амілоїдогенні мутанти, молекулярна динаміка, агрегація білків, амілоїд

A number of human disorders including systemic amyloidosis, Creutzfeld-Jacob disease, type II diabetes, Alzheimer's and Parkinson's diseases, etc. are linked to protein misfolding and self-association into amyloid fibrils, a particular type of protein aggregates with a cross- $\beta$-sheet core structure, in which hydrogen-bonded $\beta$-strands run perpendicular to the long fibril axis [1-4]. The amyloid-forming propensity is thought to be a fundamental property of polypeptide chain since proteins differing in their sequences, secondary and tertiary structures have been found to form fibrillar aggregates with the same morphology [5,6]. A variety of factors controlling the mechanisms and kinetics of amyloid formation have been identified and subdivided into two main groups. The former involves extrinsic factors, such as environmental conditions $(\mathrm{pH}$, temperature, pressure, ionic strength, extent of molecular crowding, concentration of denaturing agents or reactive oxygen species, etc.), molecular chaperone and ubiquitin-proteasome cellular systems; while the latter implicates intrinsic factors, associated with fundamental features of polypeptide chain (net charge, mean hydrophobicity, secondary structure propensities, etc.) [7,8]. Accumulating evidence lends support to the hypothesis that structural transformation of a polypeptide chain into a partially folded conformation is a critical prerequisite for fibril formation. In vitro, fibrillization-favoring conditions are created by lowering $\mathrm{pH}$, elevating temperature, adding organic solvents or denaturants, etc., while in vivo, abnormal partial unfolding or folding may arise from mutations, oxidative or heat stress or destabilization of protein structure upon adsorption at interfaces formed by cell membranes [9-12].

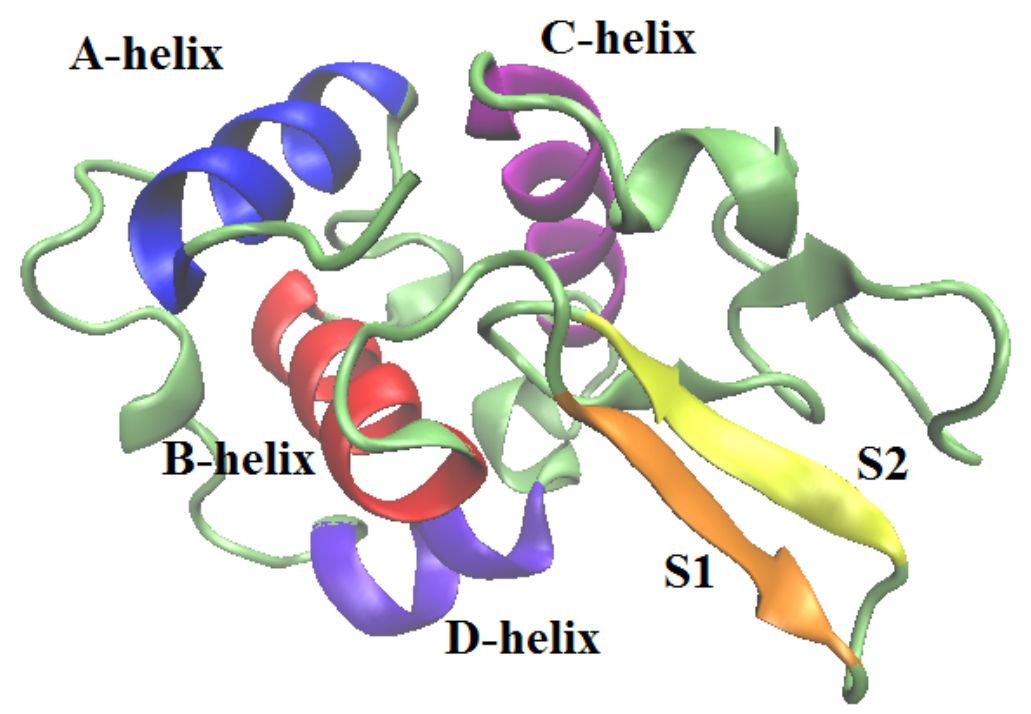

Fig. 1. Crystal structure of wild type human lysozyme (PDB ID 1REX): A-helix - residues 5-15 (blue); B-helix - residues 25-36 (red); C-helix - residues 89-100 (magenta); D-helix - residues 110-116 (violet); beta-strand S1 - residues 43-46 (orange); beta-strand S2 - residues 51-54 (yellow).

One of the most extensively studied amyloidogenic protein is lysozyme, a multifunctional enzyme with bactericidal, immunomodulatory and antitumor activities, which was found in secretions, such as sweet, saliva, mucus, etc. [13-15]. Human lysozyme consists of 130 amino acid residues which form $\alpha$-domain (residues 1-42 and 81-130) with four $\alpha$-helices (A-D) and 310 helices, and $\beta$-domain (residues 43-80) containing mainly antiparallel $\beta$-sheets [16] (Fig. 1). The structure of this protein is stabilized by four disulphide bonds located in $\alpha$-domain (C6-C128 and C30C116), $\beta$-domain (C65-C81) and in the active site, between $\alpha$ - and $\beta$-domains (C77-C95) [17]. In 1993 Pepys et al. found that two natural variants of human lysozyme, I56T and $\mathrm{D} 67 \mathrm{H}$, are related with hereditary systemic nonneuropathic amyloidosis, a disease in which amyloid fibrils deposit in viscera [18-20]. Later on, a series of other amyloidogenic mutations of lysozyme have been identified, viz. F57I, W64R, F57I/T70N, Y54N, T70N/W112R [2124]. Remarkably, most mutations are located in the $\beta$-domain, either in the long loop (W64R, D67H, T70N) or at the interface between two domains (I56T, F67I and Y54N) $[25,26]$. An exception is the mutation W112 located in the D 
helix, and in combination with T70N leads to the pathogenic aggregation [27]. Notably, the single T70N and W112R variants are not linked to disease [24,28,29], although the T70N and WT form transient intermediate species very similar to those of amyloidogenic variants formed under non-physiological conditions such as elevated temperature, low $\mathrm{pH}$ or high hydrostatic pressure [25,26,30].

To date, the most comprehensively investigated are the mutations I56T and D67H. The substitution D67 by His was found to disrupt the network of hydrogen bonds stabilizing the $\beta$-domain, especially its two long loops. This destabilization leads to significant, concerted movement of long loops and $\beta$-sheets, but such increase in flexibility is not characteristic of another pathogenic mutant, I56T and obviously does not play a primary role in the amyloidogenicity [31-34]. The substitution of stabilizing hydrophobic residue Ile at 56 position at the interface between two domains with a hydrophilic residue Thr destroys the long-range hydrophobic interactions and intramolecular hydrogen bonds at the $\alpha-\beta$ interface and accelerates the unfolding process $[26,31,33]$. The I56T variant demonstrates negligible change in crystal structure in comparison with WT protein [31,35] and significant decrease in stability, as follows from the kinetic, thermodynamic and molecular dynamics data [36]. The reduced global cooperativity under physiological and unfolding conditions [27,37,38], lower thermodynamic stability and ability to form specific transient intermediate species have been supposed to be the major molecular determinants of the amyloidogenicity of I56T and D67H variants [30,39]. Similar to these variants, the single-point mutations F57I and W64R demonstrated significant decrease in thermal stability, whereas $\mathrm{T} 70 \mathrm{~N}$ was found to be slightly destabilizing $[25,30,40]$. The non-amyloidogenic character of $\mathrm{T} 70 \mathrm{~N}$ substitution is thought to arise from the conservation of most hydrogen bonds and lack of perturbation near the interface region [25,29,35]. The mutations F57I, F57I/T70N, W64R and Y54N are supposed to destroy the hydrophobic interactions between $\alpha$ - and $\beta$-domains, thereby decreasing the hydrophobicity of the interface region $[21,25,35]$. The tryptophan residues involved in the W64R and W112R/T70N mutations presumably disrupt the hydrophobic clusters of these variants [35].

The aim of the present study was to characterize the effects of amyloidogenic mutations on the structure and dynamics of human lysozyme. To this end, we performed a series of thermal unfolding molecular dynamics (MD) simulations with WT protein and its amyloidogenic variants, I56T, D67H, F57I, W64R, Y54N, F57I/T70N and T70N/W112R.

\section{MOLECULAR DYNAMICS SIMULATIONS}

The molecular dynamics simulations were performed with GROMACS software (version 5.1) using the CHARMM36m force field with TIP3P water model [41]. The starting structure for the thermal unfolding simulations was obtained from the crystal structure of wild-type human lysozyme (PDB entry 1REX). The web-based graphical interface CHARMM-GUI was used to introduce the mutations F57I, Y54N and W64R in the WT lysozyme sequence and mutations W112R and F57I in the T70N structure (PDB entry 1W08), while the other seven mutants including I56T (1LOZ), D67H (1LYY) were taken from the PDB bank. The input files for MD calculations were prepared using the CHARMM-GUI Quick MD simulator [42].

The WT protein and mutants were solvated in the rectangular box fitted to protein size with a minimum distance of $10 \AA$ to the edges of the box. To obtain a neutral total charge of the system the required amount of potassium counterions were added. The number of atoms in the solvated protein systems varies from 22975 to 29727 . The Particle Mesh Ewald algorithm was employed to treat the long-range electrostatic interactions [43]. The minimization and equilibration of the system were performed during $100 \mathrm{ps}$ and $500 \mathrm{ps}$, respectively. The time step for MD simulations was 2 fs. The trajectories and coordinates were saved every 2 ps for further analysis. The whole time interval for MD calculations was $100 \mathrm{~ns}$. The WT lysozyme was simulated at two different temperatures, $300 \mathrm{~K}$ and $500 \mathrm{~K}$, while MD simulations of all mutants were performed at $500 \mathrm{~K}$ and a pressure 1 bar. The analysis tools provided by GROMACS were used to calculate the root mean-square deviations (RMSD), root mean-square fluctuations of the C-alpha atoms (RMSF), radius of gyration ( $\mathrm{Rg}$ ) and solvent-accessible surface area (SASA) per residue. The evolution of the secondary structure was followed using the VMD Timeline tool [44] and Tcl scripts.

\section{RESULTS AND DISCUSSION}

The thermal unfolding trajectories of WT lysozyme and its mutants were analysed in terms of the parameters reflecting the changes in both the global and local protein structure, RMSD, Rg, SASA, RMSF and the secondary structure content. As seen in Fig. 2, there are three main tendencies in RMSD behaviour, according to which all examined mutants can be divided into three groups. The first group contains the double mutant F57I/T70N and Y54N variant whose RMSDs grow faster than that of WT lysozyme (Fig. 2A). Taking the RMSD values greater than $0.7 \mathrm{~nm}$ as the unfolding criterion [45] it follows that WT protein unfolds during $\sim 10 \mathrm{~ns}$, while the unfolding times (tu) of F57I/T70N and Y54N are $~ 3 \mathrm{~ns}$ and $7 \mathrm{~ns}$, respectively. The second group includes D67H (tu $\sim 11 \mathrm{ns)} \mathrm{and} \mathrm{I56T} \mathrm{(tu} \sim 12$ ns) whose unfolding times are comparable with that of WT lysozyme (Fig. 2B), while T70N/W112R (tu $\sim 17 \mathrm{~ns}$ ), F57I (tu $\sim 21 \mathrm{~ns}$ ) and W64R (tu $\sim 24 \mathrm{~ns}$ ) that unfold slower than WT protein constitute the third group (Fig. 2C). Notably, previous unfolding simulations showed that D67H and I56T have larger RMSD values compared to WT [33,34]. The discrepancy between these findings and our results can be explained by much shorter simulation times (1 ns [33] or $5 \mathrm{~ns}$ [34]) within which RMSDs of the above mutants are indeed somewhat higher than that of WT counterpart (Fig. 2B). 

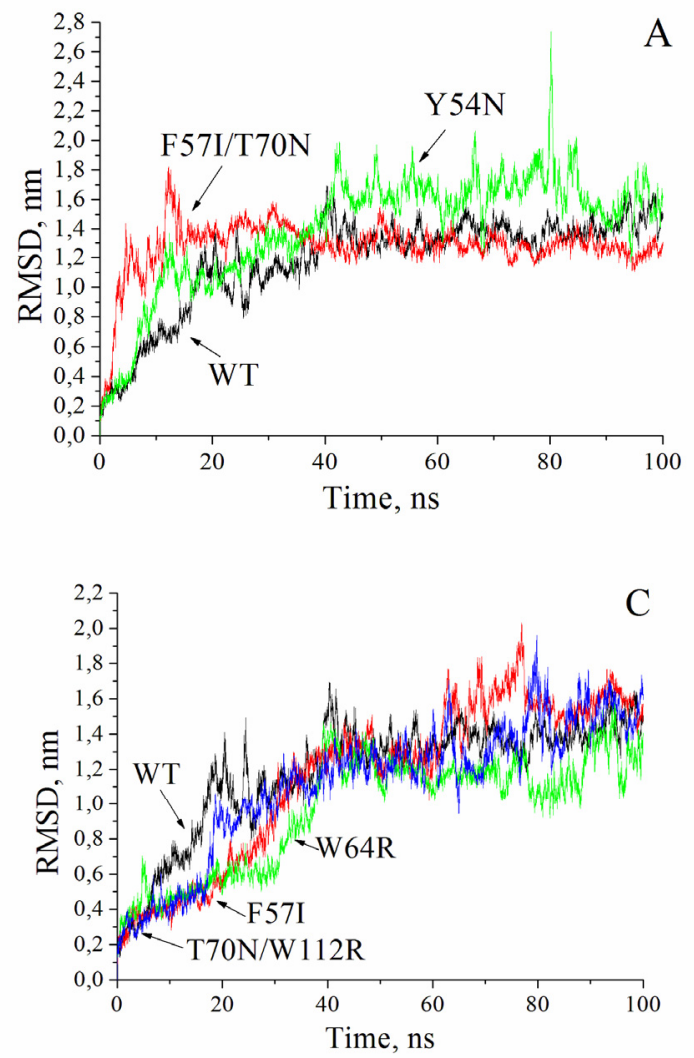

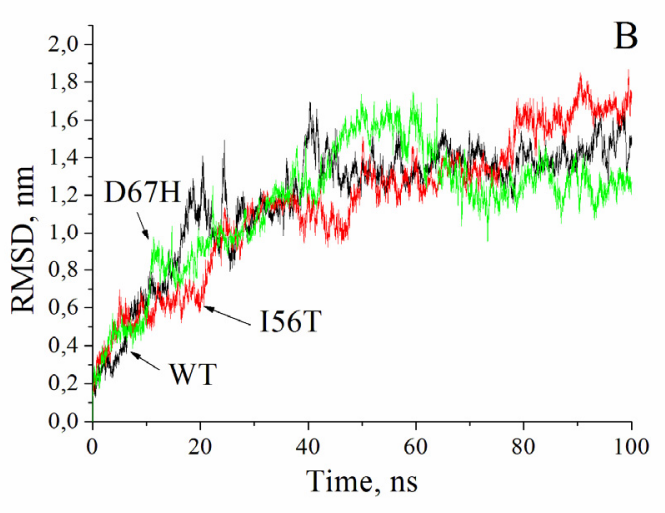

Fig. 2 The backbone root mean square deviation plotted as a function of time for the wild-type human lysozyme (black) and three groups of mutants: (A) the first group containing F57I/T70N (red) and Y54N (green); (B) I56T (red) and D67H (green) belonging to the second group; (C) F57I (red), W64R (green) and T70N/W112R (blue) constituting the third group.

Along with larger RMSD, the higher Rg and RMSF values, the loss of native contacts and secondary structure elements are all regarded as indications of the reduced stability of mutated protein [46]. The time evolutions of other integral characteristics, gyration radius and solvent accessible surface area, support the idea about three patterns of unfolding behavior of the lysozyme variants. The $\mathrm{Rg}$ value rises from $\sim 1.4$ to $\sim 1.7 \mathrm{~nm}$, while the total SASA grows from $\sim 80 \mathrm{~nm}^{2}$ to $\sim 110-115 \mathrm{~nm}^{2}$, mainly due to the changes in the hydrophobic SASA component that increases in the first $20 \mathrm{~ns}$ from $\sim 20 \mathrm{~nm}^{2}$ to $\sim 40 \mathrm{~nm}^{2}$ and further fluctuates around this value. The increase in gyration radius positively correlates with SASA changes and indicates that more residues become accessible for solvent with decreasing protein compressibility due to the loss of packing interactions [33].

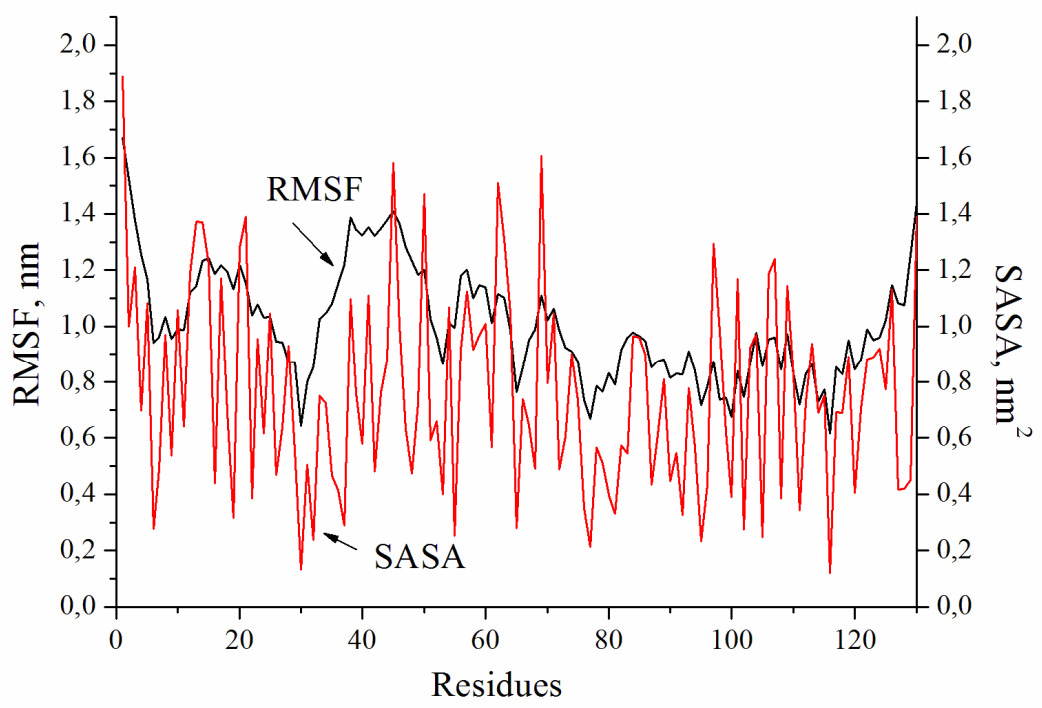

Fig. 3. The root mean square fluctuations of the $\mathrm{C}$-alpha atoms (black line) and the total solvent-accessible surface area (red line) per residue calculated from the unfolding MD trajectory of the WT human lysozyme.

Next, to characterize the influence of mutations on the lysozyme structure and dynamics in more detail, we analysed the changes in the root mean-square fluctuations of the C-alpha atoms and the total SASA per residue. Shown in Fig. 3 are the RMSF and SASA profiles calculated for the $500 \mathrm{~K}$ unfolding simulation of the WT protein. Apart from 
the $\mathrm{N}$ - and C- termini, the largest fluctuations were observed in the turn regions 15-20, 38-48 and 58-62, while most residues with the smallest fluctuations (e.g. 30, 100,116) belong to the alpha-helical regions in the native structure of lysozyme. Expectedly, the residues with the lower RMSF generally have the lesser SASA per residue (Fig. 3).
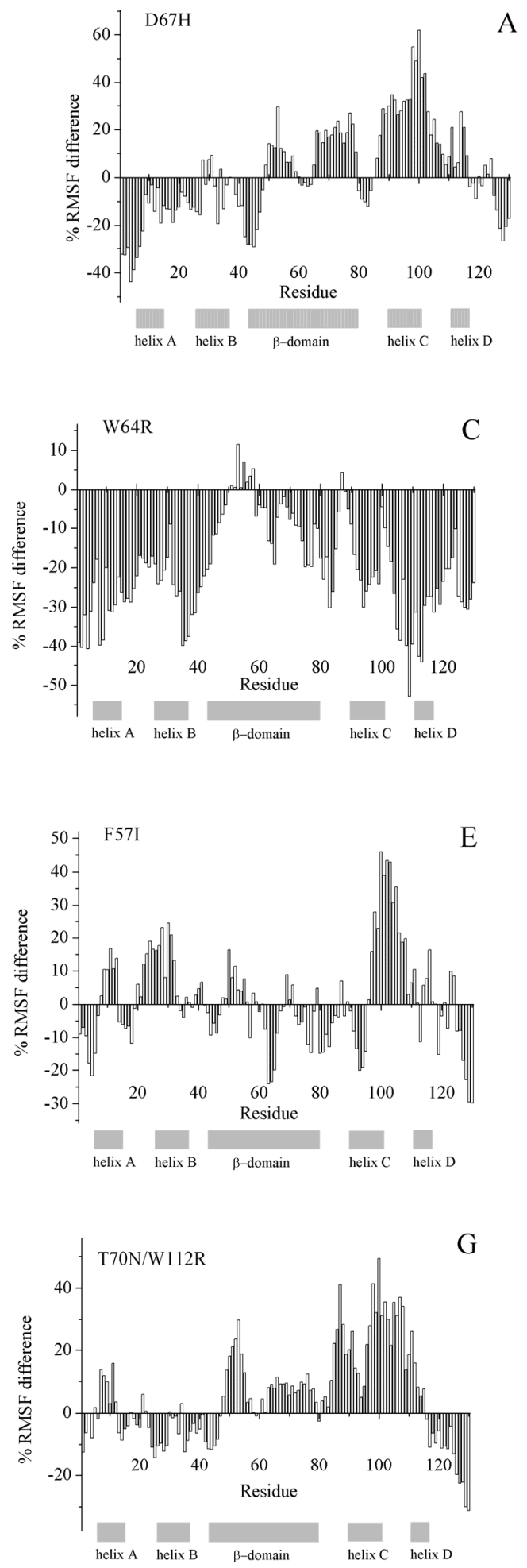
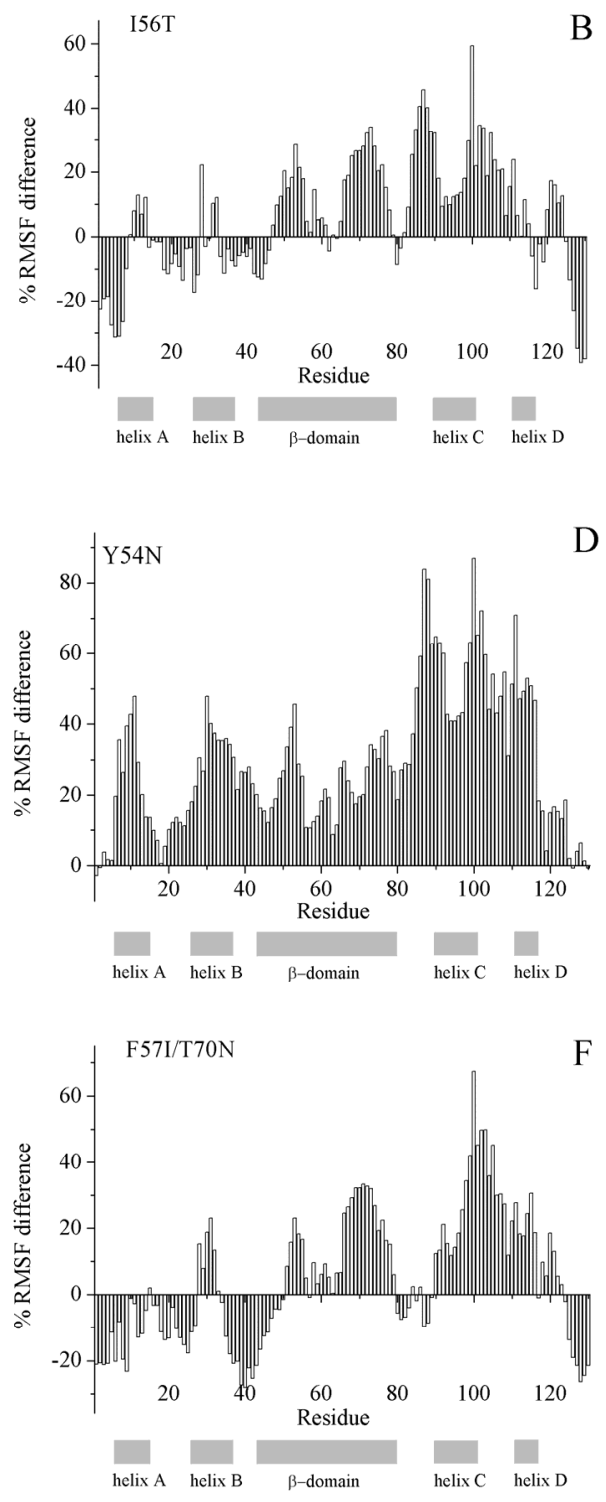

Fig. 4. The relative changes in root-mean-square fluctuations for D67H (A), I56T (B), W64R (C), Y54N (D), F57I (E), F57I/T70N (F), and T70N/W112R (G) lysozyme mutants calculated as $\left(\frac{R M S F_{m u t}}{R M S F_{W T}}-1\right) \cdot 100 \%$

It is hypothesized that the $\beta$-domain (residues 43-80), C-helix (residues 89-100) and hydrophobic core comprised of G55, I56 and F57 [47] play the predominant role in the formation of lysozyme amyloid fibrils [48,49,27]. That is why in the further consideration of the mutation-induced effects a special attention is paid to the amyloid-related and adjacent regions. The analysis of the relative changes in RMSF revealed that the region 50-60, embracing the hydrophobic core, in all mutants fluctuates stronger than in the WT protein, with the smallest differences being 
observed for W64R $(\leq 11 \%)$ and F57I $(\leq 16 \%)$ (Fig. 4). Most mutants have significantly larger fluctuations in the Cand partially D-helix and increased flexibility in the region surrounding V100, compared to the WT lysozyme, with RMSF difference ranging from $\sim 50 \%$ to $\sim 110 \%$. It is only W64R that shows the restrained motion of almost all regions, except the $\beta$-strands encompassing the residues 50-60 (Fig. 4, C). On the contrary, Y54N displays pronounced increase in the mobility of virtually all residues (Fig.4, D). It is also noteworthy that the $\beta$-domain predominantly has higher fluctuations in all mutated variants (with the exception of W64R and F57I). Our results are in line with those of Moraitakis and Goodfellow [34] who found that D67H mutation gives rise to the increased flexibility of the $\beta$-domain.
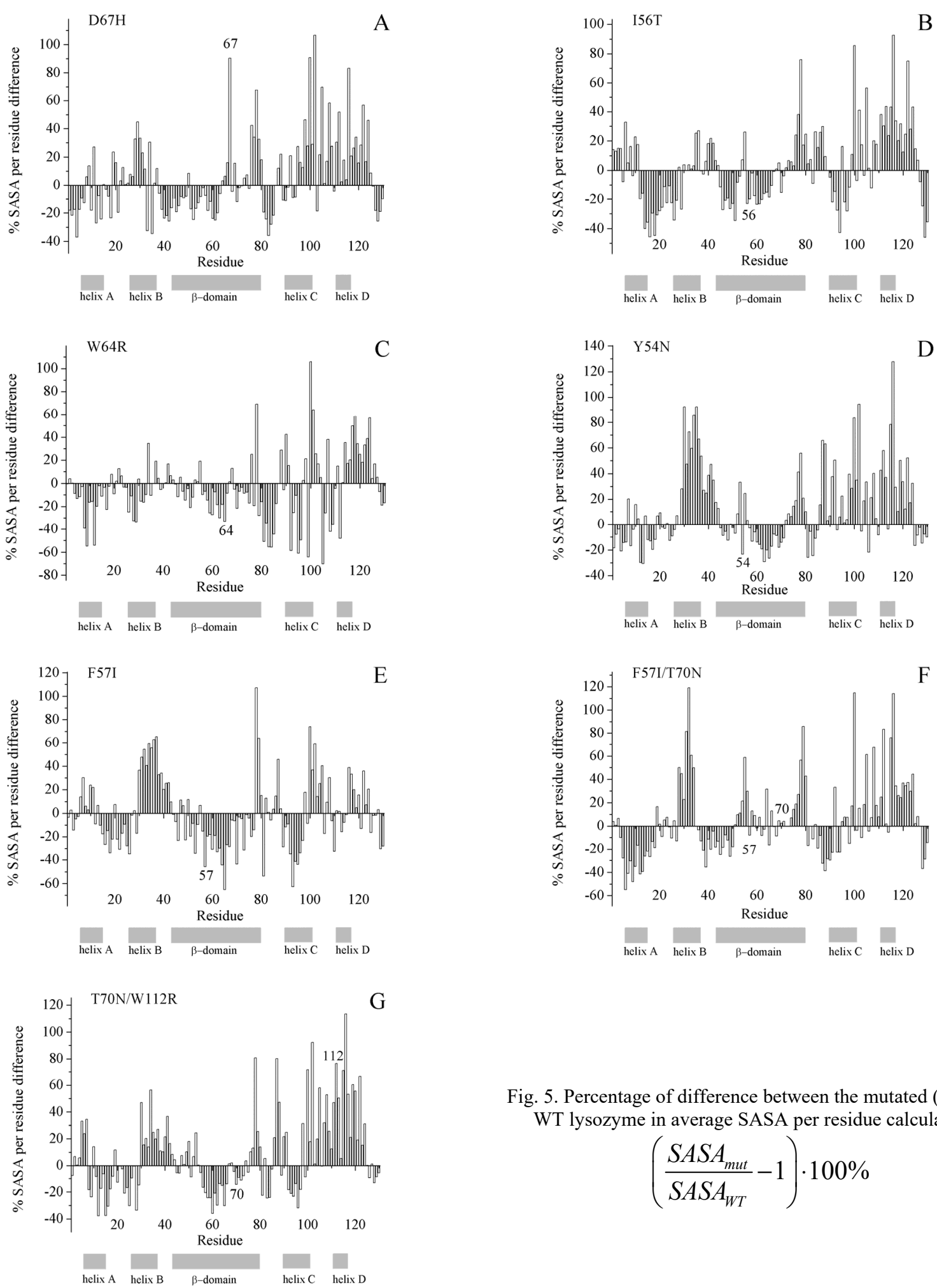

Fig. 5. Percentage of difference between the mutated (A-G) and WT lysozyme in average SASA per residue calculated as

$$
\left(\frac{S A S A_{m u t}}{S A S A_{W T}}-1\right) \cdot 100 \%
$$


Next, concentrating on the relative changes the average SASA per residue (Fig. 5), we found that for all mutants the largest increase in the solvent exposure is observed for the $\mathrm{C}$-terminal parts of the $\beta$ - and $\alpha$-domains and the region 30-36 of the B helix (especially for F57I and F57I/T70N). The increased SASA of the C helix was also observed in the previous unfolding simulation of $\mathrm{D} 67 \mathrm{H}$ [34]. Remarkably, in D67H and T70N/W112R the mutated residues show significant SASA increase ( $\sim 90 \%$ for residue 67 and $\sim 80 \%$ for residue 112$)$, while the other mutated residues, 54, 56, 57 , and 64 display the opposite SASA changes - decrease by $25-50 \%$ (Fig. 5, A-G).
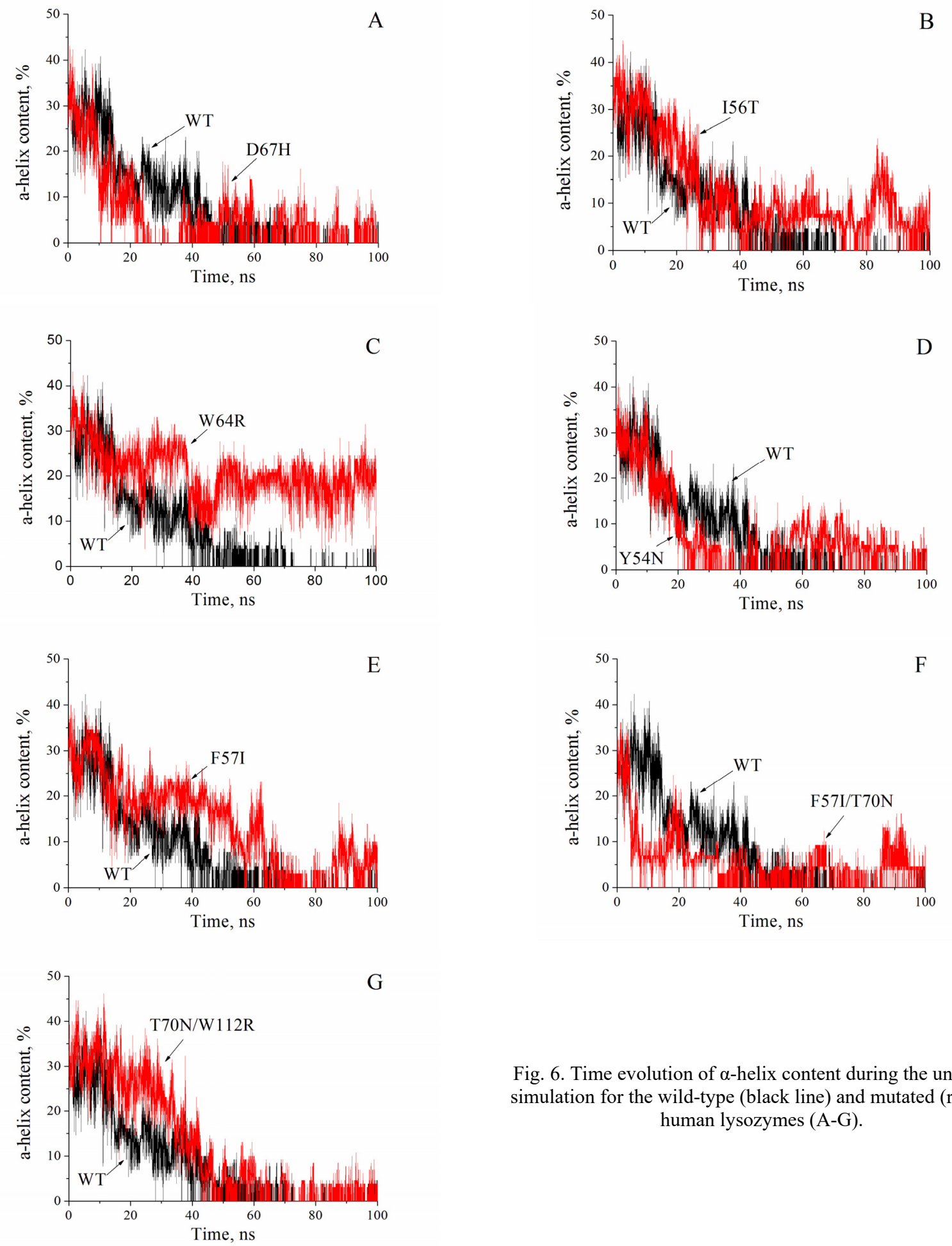

Fig. 6. Time evolution of $\alpha$-helix content during the unfolding simulation for the wild-type (black line) and mutated (red line) human lysozymes (A-G).

Importantly, for some of the examined mutants, the effects deduced from the MD simulation can be discussed in the context of the available experimental data. The comprehensive studies, involving hydrogen/deuterium exchange experiments monitored by NMR and mass spectrometry, provided evidence for the decreased stability in the native state and lower global structural cooperativity of the amyloidogenic variants I56T and D67H [32,38]. Due to such properties, 
these mutants appeared to be able to populate transient intermediate species in which the $\beta$-domain and the adjacent $\mathrm{C}$ helix are essentially unfolded whereas the A-, B- and D-helices retain their native-like structure. Furthermore, proteolysis experiments showed that the human lysozyme fragment 32-108 is highly resistant to pepsin digestion, suggesting that this region represents the core of amyloid fibrils [30]. Our observations that D67H and I56T display higher fluctuations within the region encompassing the $\beta$-domain and C-helix (Fig. 4, A, B), together with the increased solvent accessibility of the C-helix in D67H (Fig. 5, A), relative to the WT protein, generally agree with the above experimental findings. In the following, to complement the above analyses, we compared the time courses of the protein secondary structure elements. As shown in Fig. 6A, in the WT lysozyme the percentage of $\alpha$-helices reduces from $\sim 35 \%$ to $\sim 5 \%$ during $\sim 45 \mathrm{~ns}$ of the MD simulation, while the mutants exhibit different behavior. More specifically, one can distinguish three principal tendencies in the time evolution of the helical content. First, the rate of loss of helical structure in I56T, F57I and T70N/W112R seems to be similar to that of WT protein (Fig. 6, B, E, G). Second, D67H, Y54N and F57I/T70N demonstrate faster helicity decrease than WT lysozyme (Fig. 6, A, D, F). Third, the helical structure of W64R disrupts slower compared to its WT counterpart, with $\alpha$-helix content being reduced to at most $\sim 20 \%$.

To take a closer look at the mutation effect on the lysozyme unfolding pathway, we evaluated the destruction times (td) of the individual structural elements ( $\alpha$-helices and $\beta$-domain) of the lysozyme variants, considering the helix or extended conformation of the $\beta$-domain as being completely destroyed if it does not emerge within at least $1 \mathrm{~ns}$. By introducing a tentative classification of the mutation effect as stabilizing (td increases by more than $20 \%$ relative to WT), neutral (td changes lie within $\pm 20 \%$ ) and destabilizing (td decreases by more than $20 \%$ ), we uncovered additional differences between the lysozyme mutants (Table 1). The principal outcomes of the data analysis can be summarized as follows. Relative to the WT protein: (1) the D67H mutation stabilizes the B-helix and $\beta$-domain, destabilizes the C-and D- helices and exerts no influence on the A-helix; (2) the F57I mutation stabilizes the A, B, C-helices and $\beta$-domain, and destabilizes the D-helix; (3) the I56T mutation stabilizes the B, C-helices and $\beta$-domain, destabilizes the D-helix and exerts no influence on the A-helix; (4) the W64R mutation stabilizes A, C, D-helices and does not affect stability of the B-helix and the $\beta$-domain; (5) the Y54N mutation stabilizes the A and B-helices, destabilizes $\mathrm{C}$ and D-helices, and does not affect the $\beta$-domain; (6) the F57I/T70N mutation destabilizes the $\beta$-domain and all helices except the A-helix; (7) the T70N/W112R mutation stabilizes the A, B-helices and the $\beta$-domain, destabilizes the D-helix and exerts no influence on the C-helix. Taken together, these findings are indicative of the following main tendencies: i) most mutations stabilize the A- and B-helices and destabilize the D-helix; ii) the extended conformation of the $\beta$-domain is stabilized or remains unaffected by most mutations, and only one mutation, F57I/T70N, leads to more rapid conversion of the extended structure into turns and coils; iii) less stability of the $\beta$-domain compared to the $\alpha$-domain generally persists in F57I, I56T, W64R, Y54N, F57I/T70N and T70N/W112R, although being compromised by the strong destabilization of D-helix in F57I, Y54N, F57I/T70N and T70N/W112R.

Table 1.

The destruction time (ns) of the secondary structure elements of the human lysozyme variants

\begin{tabular}{|l|l|l|l|l|l|l|l|l|}
\hline $\begin{array}{l}\text { Structural } \\
\text { element }\end{array}$ & WT & D67H & F57I & I56T & W64R & Y54N & $\begin{array}{l}\text { F57I/ } \\
\text { T70N }\end{array}$ & $\begin{array}{l}\text { 770N/ } \\
\text { W112R }\end{array}$ \\
\hline $\begin{array}{l}5-15 \\
\text { Helix A }\end{array}$ & 18 & $15(\mathrm{~N})$ & $22(\mathrm{~S})$ & $21(\mathrm{~N})$ & $46(\mathrm{~S})$ & $34(\mathrm{~S})$ & $39(\mathrm{~S})$ & $49(\mathrm{~S})$ \\
\hline $\begin{array}{l}25-36 \\
\text { Helix B }\end{array}$ & 15 & $24(\mathrm{~S})$ & $64(\mathrm{~S})$ & $41(\mathrm{~S})$ & $15(\mathrm{~N})$ & $20(\mathrm{~S})$ & $7(\mathrm{D})$ & $43(\mathrm{~S})$ \\
\hline $\begin{array}{l}89-100 \\
\text { Helix C }\end{array}$ & 35 & $11(\mathrm{D})$ & $53(\mathrm{~S})$ & $65(\mathrm{~S})$ & $45(\mathrm{~S})$ & $22(\mathrm{D})$ & $5(\mathrm{D})$ & $34(\mathrm{~N})$ \\
\hline $\begin{array}{l}110-116 \\
\text { Helix D }\end{array}$ & 46 & $18(\mathrm{D})$ & $13(\mathrm{D})$ & $27(\mathrm{D})$ & $*$ & $1(\mathrm{D})$ & $0.3(\mathrm{D})$ & $14(\mathrm{D})$ \\
\hline $\begin{array}{l}1-42 \text { and } \\
\begin{array}{l}81-130 \\
\alpha \text {-domain } \\
\text { helical content }\end{array}\end{array}$ & 46.23 & 26.05 & 53.4 & 65.09 & $*$ & 22.15 & 23.57 & 34.42 \\
\hline $\begin{array}{l}43-80 \\
\beta-\text {-domain } \\
\text { extended } \\
\text { conformation }\end{array}$ & 15 & $38(\mathrm{~S})$ & $26(\mathrm{~S})$ & $23(\mathrm{~S})$ & $13(\mathrm{~N})$ & $14(\mathrm{~N})$ & $7(\mathrm{D})$ & $21(\mathrm{~S})$ \\
\hline
\end{tabular}

$\mathrm{S}$ - stabilizing, $\mathrm{N}$ - neutral, D - destabilizing effect on the destruction time, * - no destruction

The observation that most amyloidogenic mutations render the $\beta$-domain capable of retaining the extended conformation for longer period of time reinforces the view that this domain constitutes the core of amyloid fibrils formed by the human lysozyme [26,30]. 


\section{CONCLUSIONS}

To summarize, the present study indicates that amyloidogenic mutations can produce diverse effects on the structural and dynamical properties of the human lysozyme. Through monitoring the changes in parameters such as the backbone root mean-square deviation, gyration radius, solvent accessible surface area, the root mean-square fluctuations and the secondary structure content, and applying different criteria characterizing the loss of both tertiary and secondary protein structures during the thermal unfolding we found that depending on time evolution of integral characteristics the examined mutants can be tentatively divided into three groups in which RMSD, Rg and SASA show faster (Y54N and F57I/T70N), similar (D67H and I56T) and slower (W64, F57I and T70N/W112R) increase relative to the WT protein. Most mutants display higher flexibility of the C- and D-helices compared to WT, with the exception of W64R and Y54N which show marked decrease (W64R) or increase (Y54N) in mobility of almost all residues. The analysis of the time dependencies of the secondary structure content showed that the $\alpha$-domain is generally more stable than the $\beta$-domain, although the unfolding behavior of individual $\alpha$-helices is mutation dependent.

Collectively, our findings support the idea that the reduced global stability of amyloidogenic mutants is not the only determinant of protein misfolding, the local changes in conformation and dynamics of sensitive regions may also play essential role in amyloid fibril formation.

\section{ACKNOWLEDGEMENTS}

This work was partly supported by the grants No 0116U000937 and No 0117U004966 for Young Scientists from the Ministry of Education Science and of Ukraine and the grant No 0118 U002284 from the State Fund for Fundamental Research of Ukraine.

\footnotetext{
U. Tarabara (D) https://orcid.org/0000-0002-7677-0779, V. Trusova (D) http://orcid.org/0000-0002-7087-071X,

K. Vus (D) http://orcid.org/0000-0003-4738-4016, O. Ryzhova (D) http://orcid.org/0000-0001-9554-0090,

G. Gorbenko (D) http://orcid.org/0000-0002-0954-5053
}

\section{REFERENCES}

[1]. S. Meehan, T.J. Knowles, A.J. Baldwin, J.F. Smith, A.M. Squires, P. Clements, T.M. Treweek, H. Ecroyd, G.G. Tartaglia, M. Vendruscolo, C.E. Macphee, C.M. Dobson and J.A Carver, J. Mol. Biol. 372, 2007470-484 (2007).

[2]. R. Tycko, Annu. Rev. Phys. Chem. 62, 279-299 (2011).

[3]. A.W.P. Fitzpatricka, G.T .Debelouchinac, M.J. Bayroc, D.K. Clared, M.A. Caporinic, V.S. Bajajc, C.P. Jaroniec, L. Wang, V. Ladizhansky,. S.A. Müller, C.E. MacPhee, C.A. Waudby, H.R. Mott, A. De Simone, T.P.J. Knowles, H.R. Saibil, M. Vendruscolo, E.V. Orlova, R.G. Griffin and C.M. Dobson, PNAS. 14, 145468-145473 (2013).

[4]. N. Cremades and C. M. Dobson, Neurobiol. Dis. 109, 178-190 (2018).

[5]. L.S. Straub and D. Thirumalai, Annu. Rev. Phys. Chem. 62, 437-463 (2011).

[6]. F. Chiti and C. M. Dobson, Annu. Rev. Biochem. 86, 27-68 (2017).

[7]. M. Calamai, F. Chiti and C.M. Dobson, Biophys. J. 89, 4201-4210 (2005).

[8]. F. Chiti and C.M. Dobson, Annu. Rev. Biochem. 75, 333-366 (2006).

[9]. U. Sengupta, A.N. Nilson and R. Kayed, EBioMedicine. 6, 42-49 (2016).

[10]. M. Stefani, Biochim. Biophys. Acta. 1739, 5-25 (2004).

[11]. M. Belli, M. Ramazzotti and F. Chiti, EMBO reports. 12, 657-663 (2011).

[12]. Y. Liu, B. Ren, Y. Zhang, Y. Sun, Y. Chang, G. Liang, L. Xu and J. Zheng, Biochim. Biophys. Acta Biomembr. (2018) Advance online publication. doi: 10.1016/j.bbamem.2018.02.004

[13]. P.J. Artymiuk and C.C.F. Blake, J. Mol. Biol. 152, 737-762 (1981).

[14]. S. Reitamo, M. Klockars, M. Adinolfi and E.F. Osserman, La Ricerca in Clinica E in Laboratorio. 8, $211-231$ (1978).

[15]. D.M. Chipman and N. Sharon, Science. 165, 454-465 (1969).

[16]. B.G. Merlini and V. Bellotti, Clinica Chimica Acta. 357, 168-172 (2005).

[17]. T. Durek, V.Y. Torbeev and S.B.H. Kent, PNAS. 104, 4846 - 4851 (2007).

[18]. M.B. Pepys, P.N. Hawkins, D.R. Booth, D.M. Vigushin, G.A. Tennent, A.K. Soutar, N.F. Totty, O.F. Nguyen, C.C.F. Blake, C. Terry, T.G. Feest, A.M. Zalin and J. J. Hsuan, Nature. 362, 553-557 (1993).

[19]. M.M. Picken, Arch. Pathol. Lab. Med. 134, 545-551 (2010).

[20]. B. Granel, S. Valleix, J. Serratrice, P. Chérin, A. Texeira, P. Disdier, P.J. Weiller and G.O. Grateau, Medicine (Baltimore). 85, 66-73 (2006).

[21]. M. Yazaki, S.A. Farrell and M.D. Benson, Kidney International. 63, 1652-1657 (2003).

[22]. S. Valleix, S. Drunat, J.B. Philit, D. Adoue, J.C. Piette, D. Droz, B. MacGregor, D. Canet, M. Delpech and G. Grateau, Kidney International. 61, 907-912 (2002).

[23]. S. Girnius, M. Skinner, B. Spencer, T. Prokaeva, C. Bartholomew, C. O'Hara, D.C. Seldin, L.H. Connors, Amyloid. 19, $182-185$ (2012).

[24]. C. Rocken, K. Becker, M. Fandrich, V. Schroeckh, B. Stix, T. Rath, T. Kähne, J. Dierkes, A. Roessner, F.W. Albert, Hum. Mutat. 27, 119-120 (2006).

[25]. J.R.K. Johnson, J. Christodoulou, M. Dumoulin, G. Caddy, M.J. Alcocer, G.J. Murtagh, J.R. Kumita, G. Larsson, C.V. Robinson, D.B. Archer, B. Luisi and C.M. Dobson, J. Mol. Biol. 352, 823-836 (2005).

[26]. M. Ahn, C.L. Hagan, A. Bernardo-Gancedo, E. De Genst, F.N. Newby, J. Christodoulou, A. Dhulesia, M. Dumoulin, C.V. Robinson, C.M. Dobson and J.R. Kumita, Biophys. J. 111, 2358-2367 (2016).

[27]. M. Dumoulin, J.R. Kumita and C.M. Dobson, Accounts of Chemical Research. 39, 603-610 (2006). 
[28]. D.R. Booth, M.B. Pepys and P.N. Hawkins, Hum. Mutat. 16, 180 (2000).

[29]. G. Esposito, J. Garcia, P. Mangione, S. Giorgetti, A. Corazza, P. Viglino, F. Chiti, A. Andreola, P. Dumy, D. Booth, P.N. Hawkins and V. Bellotti, J. Biol. Chem. 278, 25910-25918 (2003).

[30]. E. Frare, M. Mossuto, P. Polverino de Laureto, M. Dumoulin, C. Dobson and A. Fontana, J. Mol. Biol. 361, 551-561 (2006).

[31]. D.R. Booth, M. Sunde, V. Bellotti, C.V. Robinson, W.L. Hutchinson, P.E. Fraser, P.N. Hawkins, C.M. Dobson, S.E. Radford, C.C. Blake and M.B. Pepys, Nature. 385, 787-793 (1997).

[32]. M. Dumoulin, D. Canet, A.M. Last, E. Pardon, D.B. Archer, S. Muyldermans, L. Wyns, A. Matagne, C.V. Robinson, C. Redfield and C.M. Dobson, J. Mol. Biol. 346, 773-788 (2005).

[33]. H.L. Liu, Y.C. Wu, J.H. Zhao, Y.F. Liu, C.H. Huang, H.W. Fang and Y. Ho, Biotechnology Progress. 23, 246-254 (2007).

[34]. G. Moraitakis and J.M. Goodfellow, Biophys. J. 84, 2149-2158 (2003).

[35]. A.J. Trexler and M.R. Nilsson, Science. 8, 537-557 (2007).

[36]. S. Ohnishia and K. Takano, CMLS. 61, 511-524 (2004).

[37]. L.A. Morozova-Roche, J. Zurdo, A. Spencer, W. Noppe, V. Receveur, D.B. Archer, M. Joniau and C.M. Dobson, J. Struct. Biol. 130, 339-351 (2000).

[38]. D. Canet, A.M. Last, P. Tito, M. Sunde, A. Spencer, D.B. Archer, C. Redfield, C.V. Robinson and C.M. Dobson, Nature Structural Biology. 9, 308-315 (2002).

[39]. J. Funahashi, K. Takano, K. Ogasahara, Y. Yamagata and K. Yutani, Journal of Biochemistry. 120, 1216-1223 (1996).

[40]. J.R. Kumita, J.R.K. Johnson, M.J. Alcocer, M. Dumoulin, F. Holinquist, M.G. McCammon, C.V. Robinson, D.B. Archer and C.M. Dobson, FEBS J. 273, 711-720 (2006).

[41]. J. Huang and A. MacKerell, J. Comput. Chem. 34, 2135-2145 (2013).

[42]. S. Jo, J. Lim, J. Klauda and W. Im, Biophys. J. 97, 50-58 (2009).

[43]. T. Darden, D. York and L. Pedersen, J. Chem. Phys. 98, 10089-10092 (1993).

[44]. W. Humphrey, A. Dalke and K. Schulten, J. Mol. Graph. 14, 33-38 (1996).

[45]. J. Gsponer and A. Caflisch, PNAS. 99, 6719- 6724 (2002).

[46]. R. Zhou, M. Eleftheriou, C.C. Hon, R.S. Germain, A.K. Royyuru and B.J. Berne, IBM Journal of Research and Development. 52, 19-30 (2008).

[47]. H.L. Liu, Y.C. Wu, J.H. Zhao, H.W. Fang and Y. Ho, J. Biomol. Struct. Dyn. 24, 229-238 (2006).

[48]. A. Dhulesia, N. Cremades, J.R. Kumita, S.T.D. Hsu, M.F. Mossuto, M. Dumoulin, D. Nietlispach, M. Akke, X. Salvatella and C.M. Dobson, J. Am. Chem. Soc. 132, 15580-15588 (2010).

[49]. A.K. Buell, A. Dhulesia, M.F. Mossuto, N. Cremades, J.R. Kumita, M. Dumoulin, M.E. Welland, T.P.J. Knowles, X. Salvatella and C.M. Dobson, J. Am. Chem. Soc. 133, 7737-7743 (2011). 